\title{
Influence of Valleys Terrain on Pressure of Fully Mechanized Working Faces in Shallow Coal Seams
}

\author{
YingJie Liu $(\mathbb{D}$, Qingjie Qi, and Anhu Wang 1 \\ Emergency Science Research Academy, China Coal Research Institute, China Coal Technology \& Engineering Group Co., Ltd., \\ Beijing 100070, China \\ Correspondence should be addressed to Anhu Wang; anhu163@163.com
}

Received 21 August 2020; Revised 10 November 2020; Accepted 21 December 2020; Published 7 January 2021

Academic Editor: Bangyou Jiang

Copyright (c) 2021 YingJie Liu et al. This is an open access article distributed under the Creative Commons Attribution License, which permits unrestricted use, distribution, and reproduction in any medium, provided the original work is properly cited.

The absence of a key stratum during overburden rock movement is crucial to the mining pressure of fully mechanized coal mining faces. Using physical and numerical simulations, the 21304 mechanized mining in Daliuta and Huojitu coal mining faces $1^{-2}$ appeared twice during a pressure frame accident analysis. The results indicate that a lack of key overlying strata is crucial to the mining of lower coal seams, particularly for the upper sections of a single key stratum of coal. When the key stratum of the upper coal seam is absent, a stable masonry structure is formed after mining. It is easy to form stable stacked strata at the bottom of a coal seam. When developing gullies in deep terrains, the formation of the key stratum will be an upper rock fracture affected by the impact, resulting in a partial absence of the key stratum. When the key stratum is absent, the mining of upslope working faces and the probability of dynamic strata pressure increase with the overburden on the working face and mining of downslope faces. The face mine pressure development laws on the upper and lower coal seam mining were similar, mainly manifesting as "slope section > valley bottom section > back slope section."

\section{Introduction}

In recent years, domestic and foreign experts and scholars have carried out a lot of research work on the movement rule of mining-induced overburden and the influence of key strata. Academician Qian Minggao put forward the mechanical hypothesis of "masonry beam" through in-depth research in combination with a large number of production practices, which can clearly explain the occurrence of upper overburden fracture after coal mining and the stress situation between each broken block, and explain the appearance of the stope pressure in the fully mechanized coal face [1-4]. Based on the theory of "masonry beam," some experts and scholars put forward the "key layer theory of strata control" after continuous research. By combining stope pressure, overburden migration rule, and surface subsidence, the key layer theory better explains the migration rule of overburden fracture under the influence of mining [5-9]. Jianping et al. proposed a "hyperbolic" model that fully minted the overall movement of overburden, and believed that the focus of the "hyperbolic" rock layer was located at the position of the main key layer [10]. After coal mining, according to the division of "four zones" of the overlying strata, it is proposed that the curved subsidence zone is mainly affected by the movement deformation of the closest key layer at the bottom, and the movement trajectory of subsidence is a paraboloid with elliptic shape [11]. Different roof lithologies also have a certain influence on the movement of key strata. The stopping method of filling mining can effectively reduce the movement of key strata and thus effectively control the surface subsidence deformation [12]. In addition, the theory of key strata is also helpful for surface ecological restoration. It can predict surface subsidence and fractures through the movement rules of key strata and take corresponding measures in advance to protect surface vegetation cover $[13,14]$. Extensive research has been conducted on the open mining of coal mines based on fully mechanized mining faces under complicated topography that creates abnormal pressure distributions. In the lower valley landforms, studies have been conducted on the 
anisotropy of rock mass, such as its stress value [15], and its stress concentration was mainly affected by the upper valleys of the landscape [16-18]. Some experts and scholars found $[19,20]$ that when the buried depth of the shallow coal seam was between 100 and $120 \mathrm{~m}$, under the influence of surface gully geomorphology, the ore pressure of the working face appears more strongly in the straight section of the downhill section. The size of the slope angle has also a significant influence on the mining of the working face [21-23]. Larger slope angles correspond to a thinner bedrock thickness, thereby increasing the dynamic load coefficient of the working face $[24,25]$. By using numerical simulation software to investigate the influence of complex topography on fully mechanized coal face mining, it was concluded that when the gully slope angle is less than $40^{\circ}$, the mining working face does not cause slope collapse. However, when the danger of slope landslide collapse exists during back slope mining of the working face, slope deformation is relatively small $[26,27]$. At the same time, the depth of the gully also has a certain influence on the stress distribution of the surrounding rocks. Field monitoring shows that deeper gullies correspond to larger changes in rock loss stress, specifically in the drop from valley bottom to valley peak, as well as higher stress of the original rock [28, 29].

Extensive research on the valley landform changes under the stress of working surface rock has been carried out. Because the key layer of the overlying rock is affected by the change of stress distribution, and the shallowly buried coal seam distance is close to the surface, shallow seam mining under gullies is greatly influenced by the surface topography, and shallowly buried coal seams near the surface in valleys result in a lack of key strata, thus affecting the pressure of the fully mechanized working face. For the above problems, there are few relevant research results. Based on this, the authors have studied the influence of the loss of key layers on mine pressure under ravine terrain. The study is supported by solid engineering to provide a reference for safe mining in fully mechanized mining faces under special mining conditions.

The natural environment proximal to the Huojitu coal mine is such that the surface becomes a gully landform. Gully development is particularly typical in $1^{-2}$ coal of the No. 3 panel of the 21304 working face (Figure 1) and its adjacent working face. A main ditch runs across the entire No. 3 panel, and from the main ditch into a transmitter branch, and then into five branches. The maximum head of the gully is $69.9 \mathrm{~m}$, and the angle is in the range of $25^{\circ}-40^{\circ}$. The space between the $1^{-2}$ coal seam and the upper seam of $1^{-2}$ is $7-30 \mathrm{~m}$, the average coal thickness is $4.6 \mathrm{~m}$, the coal seam dip angle is $0^{\circ}-6^{\circ}$, and cover depth is $41-198 \mathrm{~m}$. The complete working face is characterized by one-time high-back mining. As of May 2008, the top seam of the $1^{-2}$ in the No. 3 panel had all been mined. The width of the $1^{-2}$ coal seam in the 21304 working face is $240 \mathrm{~m}$, and the strike length is $3320.04 \mathrm{~m}$. The mining apparatus was equipped with an imported DBT hydraulic support with a rated resistance of $8638 \mathrm{kN}$. The machine is a JOY 7LS6C shearer. During the mining of the 21304 fully mechanized working face, the dynamic strata pressure was severe for two cases, which caused different degrees of damage to the working face.

Based on the observation data of ore pressure on the working face and the analysis of the dynamic load ore pressure phenomenon, it can be concluded that the dynamic load ore pressure mainly occurs in the upper slope section and the top slope section of the upper slope section, while in the lower slope section of the lower gully section and the straight section of the nongully terrain, the vivid load ore pressure is generally not easy to obtain. The above conclusions are also verified by the observation results of ore pressure on the working faces in different terrain sections, as shown in Table 1.

During the mining of the 21304 working face, there were two severe cases of dynamic load. The coal wall section of the working face was seriously affected, and there was a large area of roof collapse. The pressure of the working face was stronger than that of the working face that had been mined before. For the first time, a large area roof collapse violently occurred when the working face was pushed to $1875 \mathrm{~m}$, and for its geomorphologic features are the middle position of the upper slope section of the gully, the pressure data of the support were $9874-1103 \mathrm{kN}$. The impact on the coal wall in the middle of the working face of the support from No. 35-80 was serious. The front part of the support reached $2 \mathrm{~m}$, and the large-scale roof collapse was in the range of 39-59 m, the height of the roof collapse was at least $1 \mathrm{~m}$, and the maximum height was $2 \mathrm{~m}$. The amount of contraction under the column of the central bracket was generally above $180 \mathrm{~mm}$. The shrinkage of the No. 52 support was close to $210 \mathrm{~mm}$, and the safety valve of the entire working face reached 94\%. Surface observations of the location show that there is a significant crack in the location of the dynamic strata pressure, and subsidence was maximized. The maximum subsidence was $1.1 \mathrm{~m}$, and the crack width was $0.2-1.1$. For the second time, a large area of roof collapse appeared when the working face was pushed to $1947 \mathrm{~m}$. The upper geomorphologic feature was the top of the gully slope, and the pressure data of the support were in the range of $1245-1463 \mathrm{kN}$. The impact on the roofs of coal walls No. 44-70 in the middle of the working face was more serious than that of the support, and the top of the upper roof of the No. 57-60 frame was up to $2.4 \mathrm{~m}$. The maximum downward contraction of the central support column was $440 \mathrm{~mm}$. The crack width and length of the upper surface were evidently increased when compared with the first dynamic rock pressure. The maximum width was $4 \mathrm{~m}$, the length was $19 \mathrm{~m}$, and the maximum subsidence of the steps was $2.3 \mathrm{~m}$. The surface is shown in Figures 2 and 3.

Two dynamic load pressure events appeared in the 21304 working face, and two ends were relatively small, according to the measured results. The working face in the mining slope section has a weighting average interval of $19.7 \mathrm{~m}$, and a weighting average length of $1.4 \mathrm{~m}$. Mining in the bottom section of the weighting average interval of $20.1 \mathrm{~m}$ occurs with an average length of $1.2 \mathrm{~m}$. There is pressure in the slope mining section average interval of 


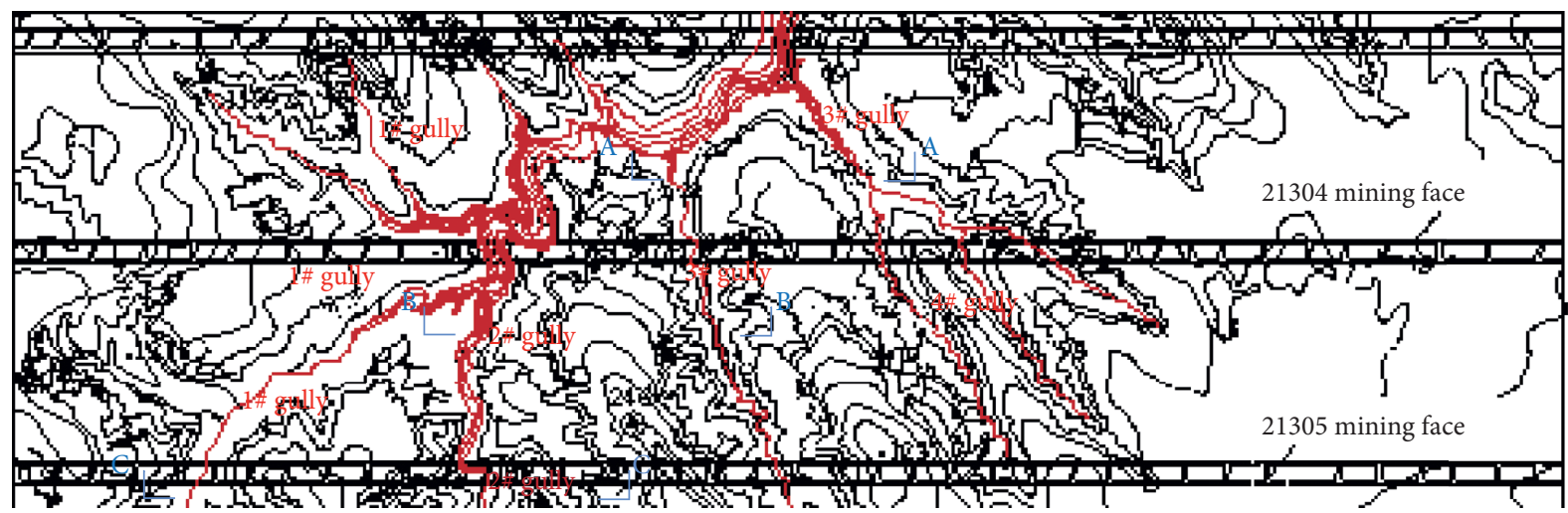

Figure 1: Surface-underground contrast plan of the No. 3 Panel $1^{-2}$ coal of the Huojitu Coal Mine.

Table 1: Pressure features in the working faces of different terrain areas.

\begin{tabular}{lcccccccc}
\hline $\begin{array}{l}\text { Geomorphic } \\
\text { type }\end{array}$ & $\begin{array}{c}\text { Pressure } \\
\text { step/m }\end{array}$ & $\begin{array}{c}\text { Pressure } \\
\text { step } \\
\text { average/m }\end{array}$ & $\begin{array}{c}\text { Continuous } \\
\text { length of } \\
\text { incoming } \\
\text { pressure/m }\end{array}$ & $\begin{array}{c}\text { Average value of } \\
\text { continuous } \\
\text { length of } \\
\text { incoming } \\
\text { pressure/m }\end{array}$ & $\begin{array}{c}\text { Maximum } \\
\text { working } \\
\text { resistance/kN }\end{array}$ & $\begin{array}{c}\text { Maximum } \\
\text { shrinkage } \\
\text { under active } \\
\text { column/mm }\end{array}$ & $\begin{array}{c}\text { Maximum } \\
\text { wall depth/ } \\
\mathrm{m}\end{array}$ & $\begin{array}{c}\text { Maximum } \\
\text { ceiling } \\
\text { height/m }\end{array}$ \\
\hline $\begin{array}{l}\text { Downhill } \\
\text { Uphill }\end{array}$ & $5.2-17.6$ & 9.5 & $0.8-6.6$ & 3.2 & 11,591 & $<50$ & $<0.8$ & $<0.5$ \\
Flat & $5.2-15.6$ & 9.6 & $1.6-8.0$ & 3.9 & 13,364 & $<1000$ & $<2$ & $<2$ \\
\hline
\end{tabular}

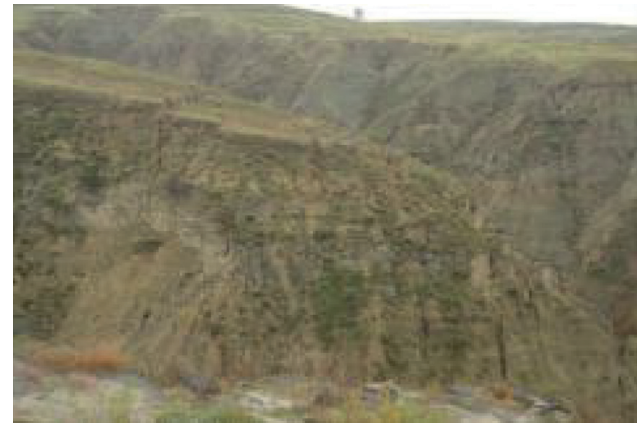

(a)

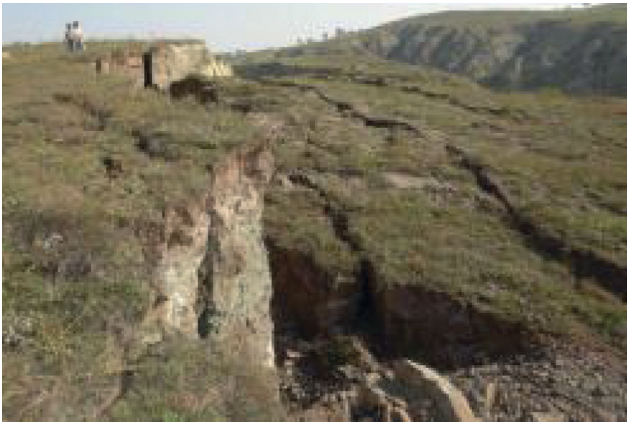

(b)

Figure 2: Field observations. (a) The first dynamic strata pressure. (b) The second dynamic strata pressure.

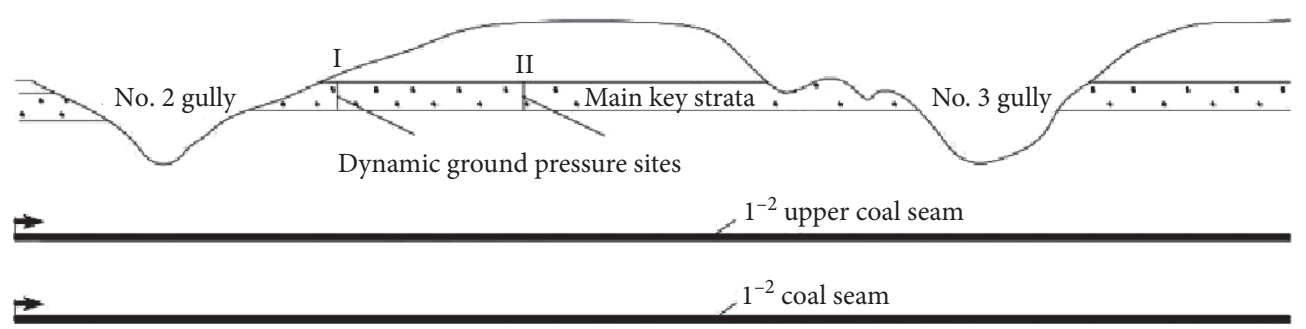

FIGURE 3: Site of dynamic strata pressure.

$18.9 \mathrm{~m}$ and the weighting average length of $1.6 \mathrm{~m}$. Therefore, backpressure slope mining and slope mining are greater compared with the average interval, and the average length is relatively small in the working face stress situation shown in Figure 4.

\section{Methodology and Analysis of the Mechanism of Instability in Key Stratum}

2.1. Identification of the Key Stratum. In this study, the key stratum of the $1^{-2}$ coal in the No. 3 panel was identified 


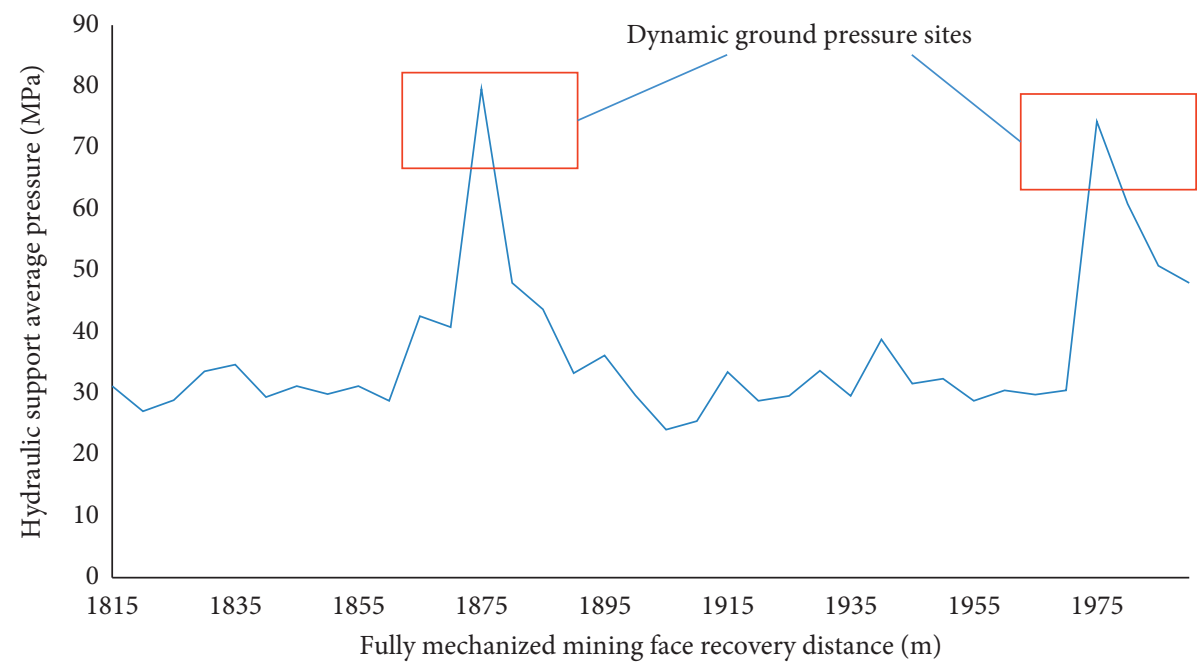

FIgURE 4: Upslope of the pressure curve of the working face.

primarily based on the existing borehole histogram of the area. Simultaneously, the key stratum was judged through computation, and the results are shown in Figure 2 [30-32]. According to the existing borehole histogram and groundmeasured level analysis, the main critical strata in this area are generally located above the valley bottom. Thus, there is no key stratum in the overburden of the gully bottom (Table 2).

Based on the analysis of the key stratum in the No. 3 panel of $1^{-2}$ coal, it was concluded that there are two key strata in the upper part of the $1^{-2}$ coal seam in the mining process, and there is only one key stratum between the $1^{-2}$ coal and the $1^{-2}$ upper coal seam because the $1^{-2}$ coal seam was mined in 2008. The key stratum of the upper coal seam broke owing to mining. Therefore, there is only one key stratum remaining in the process of $1^{-2}$ coal mining, which exists between the $1^{-2}$ coal seam and the top seam of the $1^{-2}$ coal, and the structure type is that of a single critical stratum.

The stability of the key stratum in the upper part of the $1^{-2}$ coal depends on the stability of the masonry beam structure formed by the breaking of the key stratum of the overburden after mining of the upper coal seam. If the key stratum of the $1^{-2}$ coal seam is broken after mining, it can form an extrusion and mutual frictional forces when the fractured rock blocks are arranged in order. Therefore, under certain conditions, it can form a stable structure with a semiarched appearance similar to that of the beam. If the upper coal overburden rocks are rotated toward each other, the friction produced by the squeezing force is insufficient to support the formation of a stable masonry beam structure after the breakage of the overburden rock in the upper coal seam. Owing to the influence of the overburden rock structure in the lower coal seam, instability and sliding phenomena readily appear after mining, which can directly lead to the dynamic strata pressure in the fully mechanized working face and cause a large area roof collapse.

2.2. Mechanism of Instability Caused by the Structure of the Key Stratum Overburden. According to the analysis of the aforementioned situation, there was only one critical stratum between the $1^{-2}$ coal seam and the $1^{-2}$ upper coal seam after mining of the upper coal seam was completed. Owing to the influence of the surface geomorphology on the development of the upper face of the working face, the key stratum between the $1^{-2}$ coal and $1^{-2}$ upper coal seams at the bottom of the gully was missing. Therefore, the appearance of rock pressure in the stope twice after the overbreak in the mining process resulted in a large area roof collapse and coal wall spalling. Compared with the horizontal section at the beginning of mining, the stope pressure step distance was relatively shorter, and the pressure influence range increased. The unstable conditions of the "S-R" stability component of the masonry beam hypothesis were calculated, where the sliding stability condition was as follows:

$$
h+h_{1} \leq \frac{\sigma_{c}}{30 \rho g}\left(\operatorname{tg} \varphi+\frac{3}{4} \sin \theta_{1}\right)^{2}
$$

and the rotational deformation stability condition was as follows.

$$
h+h_{1} \leq \frac{0.15 \sigma_{c}}{\rho g}\left(i^{2}-\frac{2}{3} i \sin \theta_{1}+\frac{1}{2} \sin ^{2} \theta\right) .
$$

In equations (1) and (2), $h$ and $h_{1}$ are the structural strata and load strata thickness, respectively. $\delta c$ is the unidirectional compressive strength of the strata, $\theta_{1}$ is the rotary deformation angle, $i(=h / l)$ is the ratio of the thickness to the length of the rock block, and $\operatorname{tg} \varphi$ is the coefficient of friction between rock masses, which is equal to 0.3 .

According to these calculations, in the mining process of the $1^{-2}$ upper coal seam, there were two key overlying strata. Thus, a stable masonry beam structure could be formed after the critical strata were broken. However, when coal seam $1^{-2}$ was mined, there was a single critical stratum and a stable masonry beam structure could be formed when the key stratum of the upper coal seam broke down. Thus, the mining section could also form a relatively stable masonry beam structure. In the back slope mining stage, because the front ends of the working face pushing and mining direction 
Table 2: Missing statistics of the main key stratum in the overlying strata of the No. 3 Panel from the Huojitu Coal Mine.

\begin{tabular}{lccc}
\hline Working face & Valley no. & Relative position of interface between bottom of key stratum and valley bottom (m) & Condition \\
\hline \multirow{2}{*}{21304} & 1 & +22.36 & Missing \\
& 2 & +27.13 & Missing \\
& 3 & +26.11 & Missing \\
\hline & 1 & +30.01 & Missing \\
21305 & 2 & +12.97 & Missing \\
& 3 & +2.91 & Missing \\
& 4 & -2.87 & Not missing \\
21306 & 1 & -4.12 & Not missing \\
& 2 & +5.01 & Missing \\
\hline
\end{tabular}

were toward the gully bottom when the key stratum was broken, block torsion was subjected to the horizontal pressure of the unbroken block. The increase in vertical friction between the blocks formed a stable masonry beam structure. Thus, the stope pressure was normalized, and no roof collapse occurred. At this stage of slope mining, owing to the influence of the surface structure and the lack of key stratum, the rock mass of the upper key stratum after breaking produced a large rotational deformation, which caused block instability of the stabilized masonry beam structure in the $1^{-2}$ coal seam. The load was transferred to a single critical stratum in the lower section, which led to two dynamic rock pressure events in the working face. The rotational deformation of the blocks is shown in Figures 5 and 6 .

\subsection{Simulation of Dynamic Rock Pressure on the Instability of Key Stratum Overburden}

2.3.1. Design of Indoor Physical Simulation. To verify the hypothesis of dynamic strata pressure caused by the sliding of a single main key stratum in the $1^{-2}$ coal seam, indoor physical simulations were performed at a scale of $1: 100$. Among them, the bulk density similarity ratio of the model soil was 0.71 , the stress similarity ratio was $1: 150$, and the time of push mining was $1: 10$. The main parameters of the model soil were matched with the sampling results of the No. 246 borehole, and the physical and mechanical parameters are listed in Table 3.

Because severe pressure appeared twice in the 21304 working face of the mining stage of the $1^{-2}$ coal seam toward the slope, these experiments, combined with the actual situation, simulated the mining situation of a single key stratum in the upper part of the $1^{-2}$ coal. All schemes adopted the same model parameters. The specific programs were as follows: Program I, mining simulation of the loss and absence of key stratum in the upper part of the $1^{-2}$ upper coal seam, and Program II, using the postmining test model of Plan One, $1^{-2}$ upper coal seam, the failure of overburden rock after mining in the upper coal seam of $1^{-2}$ coal seam was simulated. The model size used in the laboratory was $130 \mathrm{~cm}$ in length and $70 \mathrm{~cm}$ in height, the spacing between the two coal seam spacings was $11 \mathrm{~cm}$, and the slope angle was $30^{\circ}$. The parameters of the model are listed in Table 4.
According to the similarity simulation theory, the major similarity parameters are calculated according to formulas (3) $-(5)$ :

(1) Length ratio:

$$
\alpha_{L}=\frac{L_{H}}{L_{M}} .
$$

In equation (3), $\alpha_{L}$ is the prototype to model the length ratio. $L_{M}$ is the generalized length of the model (unit: $\mathrm{m}$ ). $L_{H}$ is the prototype generalized length $(\mathrm{m})$.

(2) Stress ratio:

$$
\alpha_{\sigma}=\frac{\sigma_{H}}{\sigma_{M}}=\frac{\gamma_{H}}{\gamma_{M}} \cdot \alpha_{L}
$$

In equation (4), $\alpha_{\sigma}$ is the stress ratio between the prototype and model. $\sigma_{M}$ is the stress model (unit: $\mathrm{MPa}) . \sigma_{H}$ is the prototype stress $(\mathrm{MPa}) . \gamma_{H}$ is the average apparent density of the coal and rock (unit: $\left.\mathrm{kg} / \mathrm{m}^{3}\right)$.

(3) Time ratio:

$$
\alpha_{t}=\frac{t_{H}}{t_{M}}=\sqrt{\alpha_{L}}
$$

In equation (5), $\alpha_{t}$ is the time ratio. $t_{H}$ is the time required for the prototype motion. $t_{M}$ is the time required for the model to move.

Based on the above similarity criteria, according to the design scheme of the model experiment, the design length ratio was 150 and the time ratio was 12.25 .

2.3.2. Analysis of Indoor Physical Simulation. According to the analysis of indoor physical test results, when mining reached $80.3 \mathrm{~m}$, as shown in Figures 7 (a) and 7 (c) when the key stratum of the overlying coal seam was missing, the upper coal seam was broken. There was no transverse pressure between the blocks, and the vertical friction 


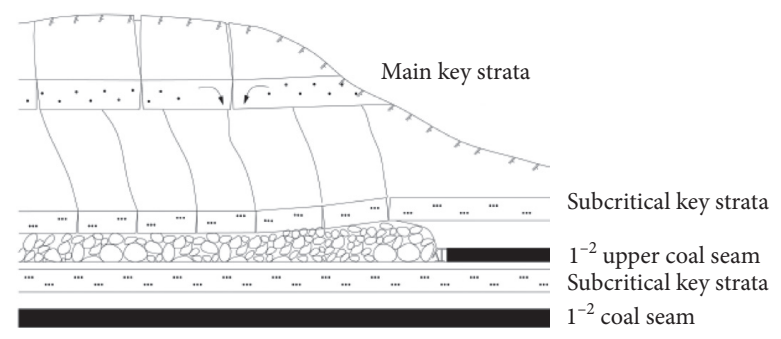

(a)

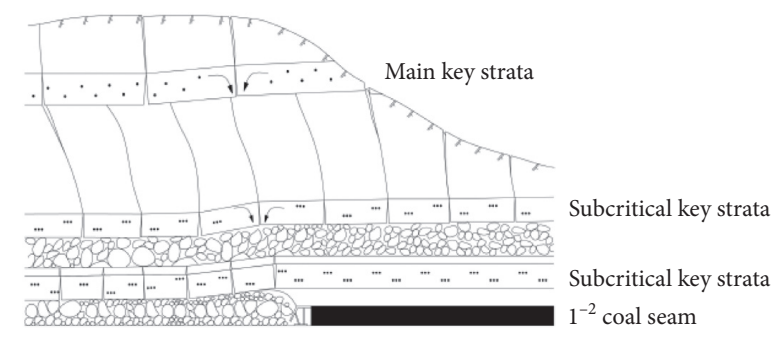

(b)

FIGURE 5: Breaking of the key stratum in downslope mining. (a) $1^{-2}$ upper coal seam. (b) $1^{-2}$ coal seam.

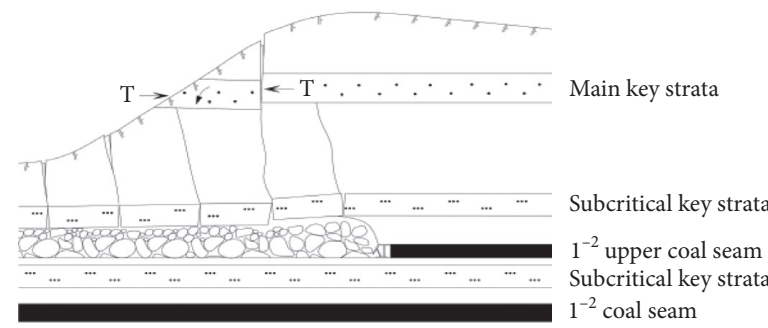

(a)

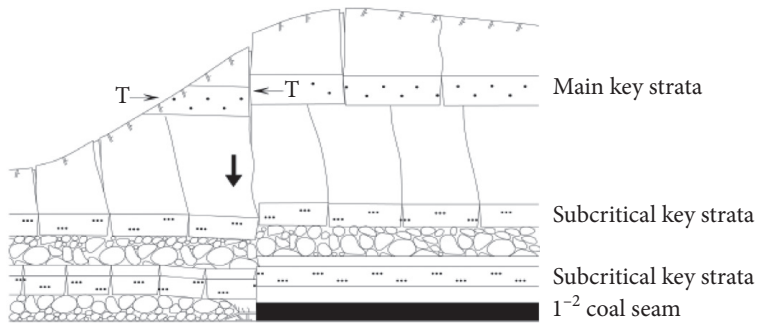

(b)

FIGURE 6: Breaking of the key stratum in the upslope mining. (a) $1^{-2}$ upper coal seam. (b) $1^{-2}$ coal seam.

TABle 3: Physical and mechanical properties of borehole strata.

\begin{tabular}{lccccc}
\hline Lithology & Poisson's ratio & Volume $\left(\mathrm{kg} / \mathrm{m}^{3}\right)$ & Elastic modulus $(\mathrm{GPa})$ & Uniaxial compressive strength $(\mathrm{MPa})$ & Internal friction angle \\
\hline Mudstone & 0.24 & 2630 & 21 & 30 & 30 \\
Poststone & 0.20 & 2700 & 47 & 29 & 36 \\
Sandy mudstone & 0.23 & 2590 & 20 & 35 & 29 \\
Kern stone & 0.23 & 2810 & 40 & 13 & 39 \\
Coal & 0.29 & 1400 & 20 & 37 & 31 \\
Siltstone & 0.24 & 2490 & 22 & &
\end{tabular}

TABle 4: Parameters of the indoor physical model.

\begin{tabular}{lcccc}
\hline Lithology & Thickness $(\mathrm{cm})$ & Compression strength $(\mathrm{MPa})$ & Volume-weight $\left(\mathrm{KN} / \mathrm{m}^{3}\right)$ & Water ratio \\
\hline Unconsolidated formation & 36 & 31.2 & 25 & 28 \\
Main key stratum & 6 & 34.3 & 25 & $1 / 8$ \\
Immediate roof & 9 & 29.9 & 14 & $1 / 6$ \\
$1^{-2}$ upper coal seam & 3.5 & 12.0 & 28 & $1 / 8$ \\
Subcritical strata & 5 & 34.0 & 25 & $1 / 8$ \\
Immediate roof & 6 & 29.8 & $1 / 8$ \\
$1^{-2}$ coal seam & 4.5 & 10 & $1 / 8$ \\
\hline
\end{tabular}

decreased. Finally, the block of the key stratum became unstable and slid down, which resulted in the dynamic strata pressure phenomenon in the mining process of the $1^{-2}$ upper coal seam. In the mining process of the $1^{-2}$ coal seam, the key stratum of the upper coal seam appeared to slip and lose stability, and a single key stratum of the upper coal seam characterized the structure of the coal seam because all the loading on the upper coal seam acted on the lower single key stratum after the onset of the instability of the upper coal seam. Therefore, in the process of mining, the stope pressure increased, resulting in a working face roof cutting phenomenon. When the upper coal seam $1^{-2}$ was mined (Figures 7(b) and $7(\mathrm{~d})$ ), owing to the integrity of the upper key stratum, the blocks of the key stratum after breaking were squeezed together during the mining process, thus forming the vertical frictional force needed to form a stable masonry beam structure. Thus, the load was in the goaf of the coal body in front and back, and the impact of the load on the lower coal seam was reduced to a great extent. Therefore, there was no dynamic strata pressure 


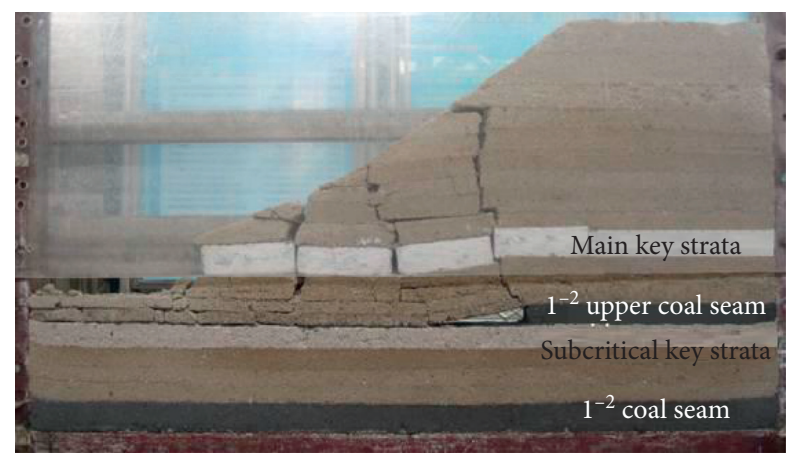

(a)

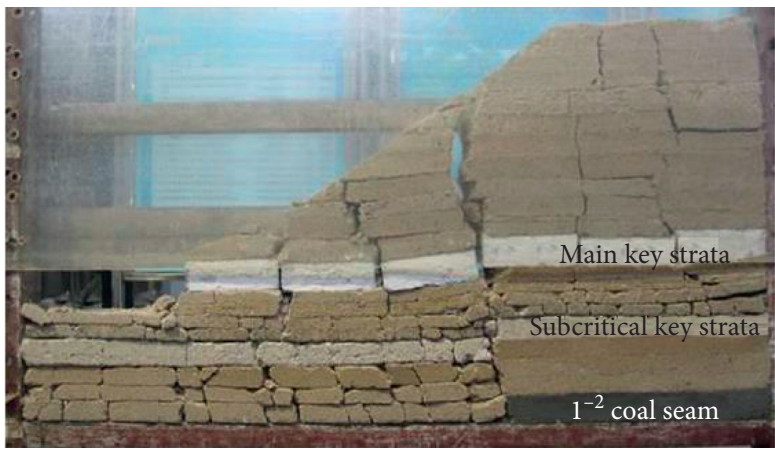

(c)

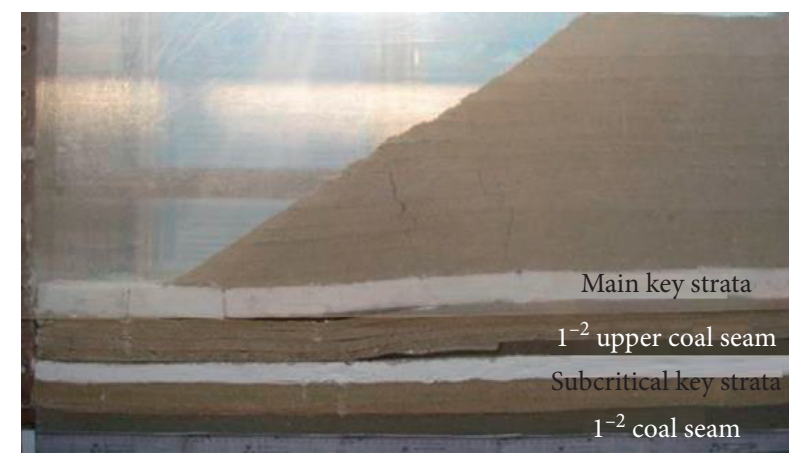

(b)

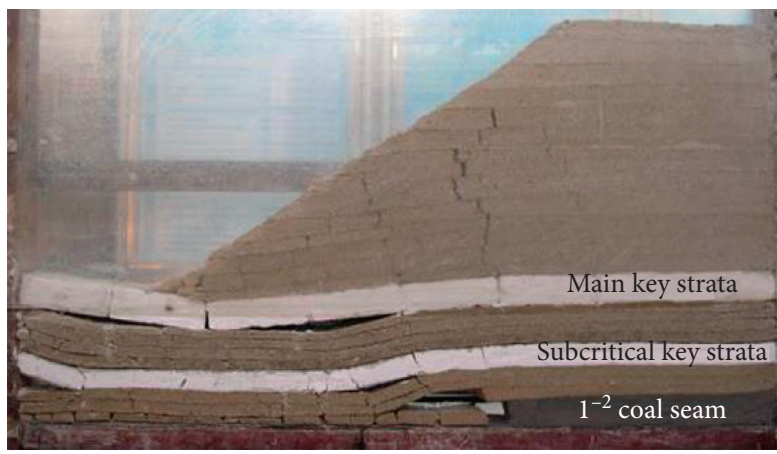

(d)

Figure 7: Comparison of main key strata absence and nonabsence recovery situation of $1^{-2}$ upper coal and $1^{-2}$ coal. (a) Absence of main key strata of $1^{-2}$ upper coal seam mining. (b) Nonabsence of main key strata of $1^{-2}$ up coal seam mining. (c) Absence of main key strata of $1^{-2}$ coal seam mining. (d) Nonabsence of main key strata of $1^{-2}$ coal.

phenomenon during the mining process. The test data are summarized in Table 5.

Under certain conditions, extrusion that occurs simultaneously to form mutual friction can form a similar appearance of a stable semiarch structure. If the final $1^{-2}$ upper strata of the coal seam between the rock friction produced by mutual rotary extrusion is not sufficient to support the formation of a stable masonry beam structure for the lower coal seam after stopping. This is because of the influence of the upper seam on the working bed structural instability, which is seen as a direct result of the fully mechanized working face that generates dynamic load pressure and causes large areas of the roof to collapse.

Therefore, when the working face passes through the gully "back slope," the overburden is smaller and the pressure step distance is larger. However, when the working face passes through the gully "front slope," the pressure step distance is opposite, and the pressure step distance is basically consistent with the theoretical analysis. During pressure building, the upper part of the working face appears to undergo tensile failure, and the rock layer above the coal seam cuts off along the rear of the hydraulic support. Greater differences between peak and peak corresponded to more obvious dynamic loads on the working surface. The strong dynamic load ore pressure was concentrated in the gully slope section, and the fractures developed vertically to the surface. In the general terrain area, the working state of the support was stable, the average pressure did not change significantly, and there was no particularly high pressure or obvious dynamic load bearing. When the working face was in the back slope section, the average resistance of the support was the least, and the resistance of the support increased rapidly after crossing the ravine. Thus, corresponding measures should be taken to reduce the impact of dynamic load ore pressure.

\subsection{Numerical Simulation of Dynamic Pressure on the Instability of Key Stratum Overburden}

2.4.1. Design of Numerical Simulation. The numerical simulation test was similar to the physical simulation test, and it was designed to simulate changes in the stope pressure in the absence of the main key stratum and the absence of the main critical strata in the upper slope section. The model length, height, slope foot ditch, and depth of both schemes were $340,105,42$, and $45^{\circ}$, respectively. The mining progress of the horizontal coal seam was $5 \mathrm{~m}$ each time, the direction was from the foot of the slope, and the supporting strength of the two coal strata was $5 \mathrm{~m}$. The support strength of the $1^{-2}$ upper coal 
TABLE 5: Effect of absent/present strata on the stress of the main key stratum.

\begin{tabular}{|c|c|c|c|}
\hline Coal seam & Main pressure index of the stope & Missing the main key stratum & Not missing the main key stratum \\
\hline \multirow{6}{*}{$1^{-2}$ upper coal seam } & Initial pressure step $/ \mathrm{m}$ & 22 & 26 \\
\hline & Periodic mean pressure step $/ \mathrm{m}$ & 9.1 & 16.2 \\
\hline & Maximum height of ground steps/m & 3 & 0 \\
\hline & Maximum height of ground $\mathrm{crack} / \mathrm{m}$ & 3.7 & 0.2 \\
\hline & Main key stratum instability & Yes & No \\
\hline & Times of dynamic strata manifestation/times & 3 & 0 \\
\hline \multirow{7}{*}{$1^{-2}$ coal seam } & Initial pressure step $/ \mathrm{m}$ & 30 & 29 \\
\hline & Periodic mean pressure step $/ \mathrm{m}$ & 7.8 & 8.7 \\
\hline & Maximum height of ground steps $/ \mathrm{m}$ & 3.4 & 0 \\
\hline & Maximum height of ground $\mathrm{crack} / \mathrm{m}$ & 5.1 & 0.5 \\
\hline & Main key stratum instability & Yes & No \\
\hline & Subcritical strata instability & Yes & No \\
\hline & Times of dynamic strata manifestation/times & 1 & 0 \\
\hline
\end{tabular}

seam was $1 \mathrm{MPa}$, and the support strength of the $1^{-2}$ coal was $1.5 \mathrm{MPa}$.

The yield criterion of the Mohr-Coulomb elastoplastic constitutive model was adopted in the numerical simulation study:

$$
f_{s}=\sigma_{1}-\sigma_{3} \frac{1+\sin \varphi}{1-\sin \varphi}-2 c \sqrt{\frac{1+\sin \varphi}{1-\sin \varphi}}
$$

In equation (6), $\sigma_{1}$ is the maximum principal stress. $\sigma_{3}$ is the minimum principal stress. $c$ is the cohesion. $\varphi$ is the internal friction angle.

The calculation model diagram is shown in Figure 8. The detailed parameters are listed in Table 6.

The valley area was set as a benchmark value of $0 \mathrm{~m}$. In the simulation scheme, datum height was negative below the datum surface and each layer face was flat on the ground. The apparent pressure numerical data in the valleys of the downhill section, as well as the groove and upslope segments of the mine, were compared. An index was adopted to measure the dynamic load rock pressure manifestation degree on the working face under the support of a large periodic weighting. This index accounted for surface crack width, crack height, and ground height. The Mohr-Coulomb yield criterion was used for surrounding rock failure.

2.4.2. Numerical Simulation Analysis. The working face of the $1^{-2}$ upper coal seam is in the gully area. The gully slope during the period and groove, face pressure, and normal pressure manifestation are smaller under the support column drop-off, with a maximum of $220 \mathrm{~mm}$, a ground bench height of $150 \mathrm{~mm}$, and the largest crack width of $50 \mathrm{~mm}$ at its maximum. The main key stratum above the working face block remained stable.

When the working face advanced $240 \mathrm{~m}$ into the valleys uphill, it faced a strong, dynamic load pressure. The face with the greatest support to exist under the column drop-off was $720 \mathrm{~mm}$, with a maximum ground step height of $670 \mathrm{~mm}$ and a crack width of $40 \mathrm{~mm}$. The main reason for this is that the key layer breaking the main block because of the lack of horizontal stress structure stability is poorer, and the second is that there is an increase in the slope angle and in the key stratum overburden load. Therefore, the block final sliding instability is easily generated, resulting in a working face and dynamic pressure. The pressure curve is shown in Figure 9.

Face from the valley areas to slope and bottom topography, rock movement, and the bracket deformation characteristics are similar to mining in coal seams. The impact of mining coal seam working faces and advancing is limited. The key stratum structural block remains in a stable condition, and the working pressure is normal. In reality, the column shrank under the maximum of $260 \mathrm{~mm}$, with a maximum height of $330 \mathrm{~mm}$, and crack width of $90 \mathrm{~mm}$.

During the period in which the working face is advanced into uphill valleys, a dynamic load occurs at the location of the mine pressure and the dynamic pressure face again, when the mining coal seam is $240 \mathrm{~m}$. For a face with the largest live column under the drop-off of $1300 \mathrm{~mm}$, the ground bench height is $3350 \mathrm{~mm}$, and the largest crack width is $200 \mathrm{~mm}$. Breaking is the main reason why the main key stratum is considered to have poorer structural stability. The secondary disturbance of sliding instability may again produce the key structure of the layer 2 block overburden, wherein load increases with sliding instability also appearing, resulting in a working face production life column with a sharp shrinkage, and cutting the top dynamic load pressure of the surrounding rock. The pressure curve is shown in Figure 10.

On the $1^{-2}$ coal seam working face, the slope is pushed to $220 \mathrm{~m}$ because of the upper key stratum horizontal stress with the final block. The block between vertical friction sources is sufficiently strong to support the upper layer, and its load leads to a dynamic load working pressure. The hydraulic support column schedule shrinkage is then under $0.5 \mathrm{~m}$, the ground benchtop head is $0.51 \mathrm{~m}$, and the surface crack width is up to $0.11 \mathrm{~m}$. In the $1^{-2}$ coal seam working face slope push to reach $220 \mathrm{~m}$, the upper coal seam appears here because the main key stratum instability has experienced a dynamic load pressure phenomenon. Therefore, the location of the upper section is not a stable fracture after coal mining on the block masonry beam structure and the upper loads on the key layer 2 cause the key stratum to slide a strong and dynamic phenomenon of 


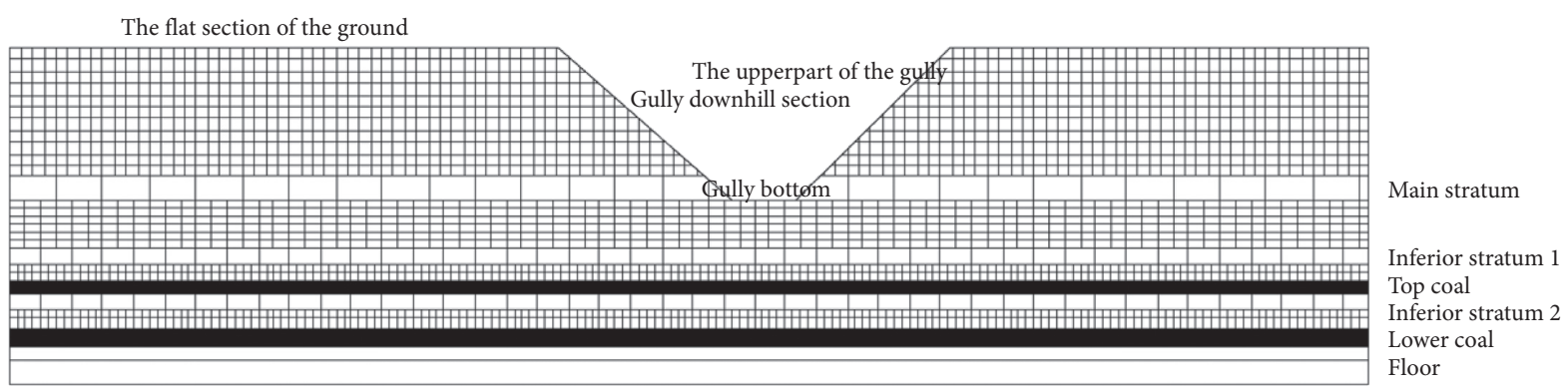

FIgURE 8: Numerical model calculation.

TABle 6: Parameters of the numerical model of rock strata.

\begin{tabular}{|c|c|c|c|c|c|c|c|c|}
\hline Stratum & $\begin{array}{l}\text { Thickness } \\
(\mathrm{cm})\end{array}$ & $\begin{array}{c}\text { Volume- } \\
\text { weight } \\
\left(\mathrm{KN} / \mathrm{m}^{3}\right)\end{array}$ & $\begin{array}{c}\text { Bulk } \\
\text { modulus } \\
(\mathrm{GPa})\end{array}$ & $\begin{array}{c}\text { Shear } \\
\text { modulus } \\
(\mathrm{GPa})\end{array}$ & $\begin{array}{c}\text { Internal } \\
\text { friction } \\
\text { angle }\end{array}$ & $\begin{array}{c}\text { Tensile } \\
\text { strength } \\
(\mathrm{MPa})\end{array}$ & $\begin{array}{c}\text { Cohesive } \\
\text { strength } \\
(\mathrm{MPa})\end{array}$ & $\begin{array}{l}\text { Model unit } \\
\text { volume }\left(\mathrm{m}^{2}\right)\end{array}$ \\
\hline $\begin{array}{l}\text { Unconsolidated } \\
\text { formation }\end{array}$ & 34 & 25 & 14 & 8 & 30 & 1.3 & 2.5 & \\
\hline Main key stratum & 8 & 28 & 32 & 20 & 36 & 2.4 & 4.9 & $14 \times 8$ \\
\hline Sandy mudstone & 15 & 26 & 10 & 5 & 24 & 1.1 & 2.2 & $5 \times 3$ \\
\hline Subcritical strata 1 & 5 & 28 & 19 & 14 & 28 & 1.6 & 3.8 & $10 \times 6$ \\
\hline $\begin{array}{l}1^{-2} \text { upper coal } \\
\text { immediate roof }\end{array}$ & 9 & 25 & 10 & 5 & 24 & 1.1 & 2.2 & $3 \times 3$ \\
\hline $1^{-2}$ upper coal seam & 3.5 & 14 & 6 & 4 & 22 & 0.8 & 1.8 & $5 \times 4.5$ \\
\hline Subcritical strata 2 & 5 & 28 & 19 & 14 & 28 & 1.6 & 3.8 & $10 \times 6$ \\
\hline $\begin{array}{l}1^{-2} \text { coal immediate } \\
\text { roof }\end{array}$ & 6 & 25 & 10 & 5 & 24 & 1.1 & 2.2 & $3 \times 3.5$ \\
\hline $1^{-2}$ coal seam & 4.5 & 14 & 6 & 4 & 22 & 0.8 & 1.8 & $5 \times 3.5$ \\
\hline Bottom plate & 15 & 28 & 19 & 14 & 28 & 1.6 & 3.8 & \\
\hline
\end{tabular}

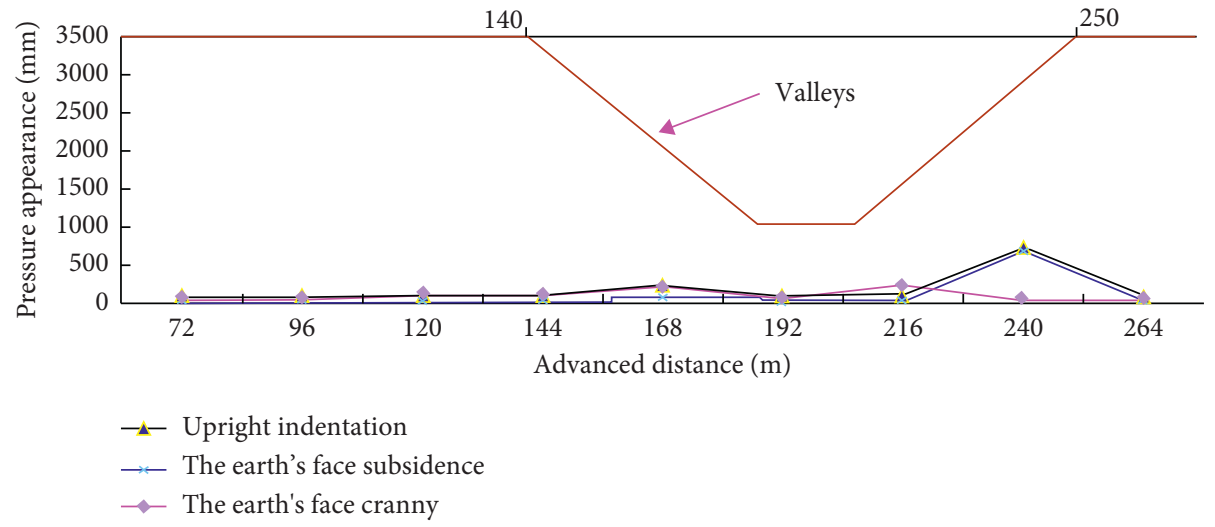

FIgURE 9: Pressure curve of coal $1^{-2}$.

underground pressure, hydraulic support pillar shrinkage under $1.2 \mathrm{~m}$, a ground level drop of $2.2 \mathrm{~m}$, and a surface crack width of $0.26 \mathrm{~m}$.

Therefore, according to the research results, it can be considered that the roof stress field changes with the changes in the terrain during working face mining, which is specifically reflected in the following aspects: the vertical stress of the roof in the gully section is greater than that in the general topographic section.
2.5. Comparison of Numerical and Physical Simulation Results. When the lack of key stratum is not effective for slope mining, the influence of mining after fracture blocks between rotary deformation is small, lateral forces between blocks are larger, and it is easy to form a stable masonry beam structure. The stability of the masonry beam structure is formed after mining of the upper coal seam, and lower coal seam mining is not generally affected by the dynamic load pressure. However, when there is missing work for key 


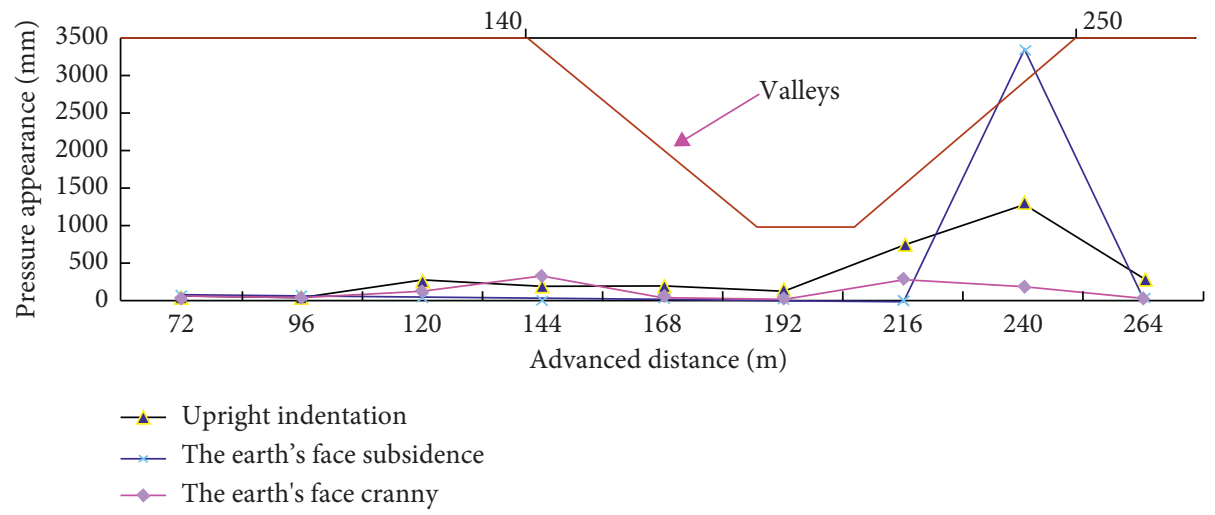

Figure 10: Pressure curve of coal $1^{-2}$ upper.

stratum slope mining, stability will be noted after coal seam mining, and the working face top load will increase gradually. Therefore, it is easy for a fault block slide to occur along the working face under dynamic load mine pressures after mining the upper coal load. When the slope at the lower coal seam mining stope pressure shows an increasing trend, slide instability and dynamic load pressure are produced. The results of similar simulation experiments are highly consistent with those of the numerical simulation experiment.

\section{Conclusions}

In the mining process of shallowly buried coal seams in a fully mechanized working face, the key stratum plays an important role in controlling the movement of overburden. By analyzing the conditions of two intense pressures in the $1^{-2}$ coal of 21304 fully mechanized working face of the Huojitu coal mine, it was determined that when the main key stratum is present after mining in the upper coal seam, a stable masonry beam structure can withstand certain loads owing to the crushing of broken blocks. When the lower coal seam is mined, a good masonry beam structure can also be formed under normal circumstances to ensure that the fully mechanized working face is not affected by rock bursts during the mining process.

When the main key stratum is missing after mining in the upper coal seam, it is not easy to form a stable masonry beam structure because of the small lateral force between the broken blocks and the larger ones. When the lower coal seam is mined because the upper part of the coal seam does not form a stable masonry beam structure, the load formed by the upper strata after mining acts on the key stratum of the lower coal seam. Therefore, when the key stratum of the lower coal seam cannot bear the upper load pressure, the working face stope pressure increases violently with the dynamic strata pressure.

Whether the key stratum of shallow coal seams is considerably affected by surface gully topography, when the gully is deep, the key stratum in the upper section of the coal seam is missing. When working face slope mining, the load on the coal seam increased gradually, and when it reached a certain critical value, the working face was affected by the dynamic strata pressure. The load on the coal seam decreased gradually when the back slope was mined. Thus, it is not easy for the back slope section to influence the dynamic strata pressure.

The influence of the valley terrain on the working face pressure in shallowly buried coal seam mining appears to be relatively strong. The mine pressure regularity analysis shows that the pressure law in the coal mining working faces is similar, mainly manifesting as "slope section >valley bottom section >back slope section.”

\section{Data Availability}

The data used to support the findings of this study are included within the article.

\section{Conflicts of Interest}

There are no conflicts of interest regarding the publication of this paper.

\section{Acknowledgments}

This work was financially supported by China Coal Technology \& Engineering Group Co., Ltd. (2019-2-ZD003), China Postdoctoral Science Foundation (2020M680490), and the State Key Research and Development Program (2017YFC0804310).

\section{References}

[1] M. G. Qian and H. C. Li, "The law of overlying strata movement and its influence on the pressure of mine," Coal, no. 2, pp. 1-8, 1982.

[2] H. C. Li and M. G. Qian, "Study on ascending mining of Kongzhuang coal mine," China University Mining Technology, no. 2, pp. 12-24, 1982.

[3] M. G. Qian, "Structural models of overlying strata in longwall faces and their application," China University Mining Technology, no. 2, pp. 1-11, 1982.

[4] M. G. Qian, "A study of the behavior of overlying strata in longwall mining and its application to strata control," Developments in Geotechnical Engineering,Strata Mechanics, vol. 32, pp. 13-17, 1982. 
[5] M. G. Qian, X. X. Miu, J. L. Xu et al., Key Stratum Theory of Strata Control, China Coal Publishing Press, Beijing, China, 2003.

[6] J. L. Xu and W. Qin, "Accumulative effect of overburden strata expansion induced by stress relief," Journal of China Coal Society, vol. 45, no. 1, pp. 35-43, 2020.

[7] J. Z. Yang and Q. J. Liu, "Analysis and measured of strata behavior law and mechanism of $8.8 \mathrm{~m}$ ultra-high mining height working face," Coal Science and Technology, vol. 48, no. 1, pp. 69-74, 2020.

[8] J. Xu, D. Xuan, W. Zhu, X. Wang, B. Wang, and H. Teng, "Study and application of coal mining with partial back filling," Journal of China Coal Society, vol. 40, no. 6, pp. 1303-1312, 2015.

[9] J. L. Xu and M. G. Qian, "Method to distinguish key stratum in overburden," China University Mining Technology, vol. 29, no. 5, pp. 464-467, 2000.

[10] J. L. Xu and M. G. Qian, "Study and application of dominant stratum theory for control of strata movement," China Mining Magazine, vol. 10, no. 6, pp. 54-56, 2001.

[11] D. L. Zhang, "Strata control in fully-Mechanized sub-level caving face," Shandong University Science Technology, vol. 19, no. 1 , pp. 8-11, 2000.

[12] X. X. MiuX. B. Mao et al., "Composite effect analysis of key stratum in mining overburden strata," Mine Pressure and Roof Management, pp. 19-25, 1999.

[13] X. X. Miu and X. B. Mao, "Advance in the key stratum theory of mining rock mass," China University Mining Technology, vol. 29, no. 1, pp. 25-29, 2000.

[14] Y. P. Liang and B. Li, "Moving type of key strata and its influence on ground pressure in fully mechanized mining face with large mining height," Journal of China Coal Society, vol. 41, no. 6, pp. 279-286, 2017.

[15] R. Singh, T. N. Singh, and B. B. Dhar, "Coal pillar loading in shallow mining conditions," International Journal of Rock Mechanics and Mining Sciences \& Geomechanics Abstracts, vol. 33, no. 8, pp. 757-768, 1996.

[16] X. Li, S. J. Wang, T. Y. Liu, and F. S. Ma, "Engineering geology, ground surface movement and fissures induced by underground mining in the Jinchuan Nickel Mine," Engineering Geology, vol. 76, no. 1-2, pp. 93-107, 2004.

[17] Y. Najjar and M. Zaman, "Numerical modeling of ground subsidence due to mining," American Rock Mechanics Association, vol. 30, pp. 1445-1448, 1993.

[18] Q. C. Wang and Y. F. Zhao, "Observation of ore pressure in shallow buried working face," Mine Pressure and Roof Management, vol. 21, no. 3, pp. 82-84, 2004.

[19] Q. C. Wang, Observation of Ore Pressure in Working Face 12205 of Live Chicken and Rabbit Coal Mine, Jiangxi Coal Technology, Yichun, China, 2005.

[20] X. F. WangD. S. Zhang et al., "Development characteristics of mining pressure under sandy soil gully slope in shallow buried coal seam," Coal Science and Technology, vol. 6, pp. 18-22, 2010.

[21] X. F. WangD. S. Zhu et al., "Underground pressure characteristics analysis in back-gully mining of shallow coal seam under a bedrock gully slope," Mining Science and Technology, vol. 21, no. 1, pp. 23-27, 2011.

[22] Z. Zhang, J. Xu, W. Zhu, and Z. Shan, "Simulation research on the influence of eroded primary key strata on dynamic strata pressure of shallow coal seams in gully terrain," International Journal of Mining Science and Technology, vol. 22, no. 1, pp. 51-55, 2012.
[23] Z. Q. ZhangJ. L. Xu et al., "Study on the law of coal pressure in shallow coal seam under gully topography," China Coal, vol. 37, no. 6, pp. 55-58, 2011.

[24] Z. Q. ZhangJ. L. Xu et al., "Study on the influence of gully slope Angle on the pressure of shallow coal seam working face," Journal of Mining and Safety Engineering, vol. 28, no. 4, pp. 560-565, 2011.

[25] Y. Gong and F. Q. Tang, "Numerical simulation study on mining subsidence deformation in Western Loess Mountainous area," Journal of Xi'an University of Science and Technology, vol. 32, no. 4, pp. 490-494, 2012.

[26] Y. X. Qiu, Study on the Formation Mechanism of Mining Collapse Disaster in Gully Cut Shallow Buried Area, Xi'an University of Science and Technology, Xi'an, China, 2012.

[27] W. H. Li, Study on the Influence Law of Gully Occurrence on the Key Layer Fracture of Shallow Coal Seam Working Face, China University of Mining and Technology, Xuzhou, China, 2016.

[28] J. ZhaoC. Y. Liu et al., "Three-dimensional geological modeling of shallow coal seam mining in gully area and research on surface damage," Journal of Mining and Safety Engineering, vol. 35, no. 5, pp. 969-977, 2018.

[29] J. W. LiC. Y. Liu et al., "Study on occurrence mechanism and control of mining pressure in shallow buried coal seam in gully area," Coal Science and Technology, vol. 46, no. 9, pp. 104-110, 2018.

[30] Q. X. Huang and Z. J. L. Zhou, "Roof weighting behavior and roof structure of large mining height longwall face in shallow coal seam," Journal of China Coal Society, vol. 45, no. S2, pp. 279-286, 2016.

[31] J. L. Xu and J. F. Ju, "Structural morphology of key stratum and its influence on strata behaviors in fully mechanized face with super-large mining height," Chinese Journal of Rock Mechanics and Engineering, vol. 30, no. 8, pp. 1547-1556, 2011.

[32] S. Huang, Y. Lyu, Y. Peng, and M. Huang, "Analysis of factors influencing rockfall runout distance and prediction model based on an improved KNN algorithm," IEEE access, vol. 7, pp. 66739-66752, 2019. 